\title{
Multi-drug resistant toxigenic Vibrio cholerae 01 is persistent in water sources in New Bell-Douala, Cameroon
}

\author{
Jane-Francis Tatah Kihla Akoachere ${ }^{1,2^{*}}$, Thomas Njinuwoh Masalla ${ }^{1,2}$ and Henry Akum Njom²
}

\begin{abstract}
Background: Cholera has been endemic in Douala, since 1971 when it was first recorded in Cameroon. Outbreaks have often started in slum areas of the city including New Bell. Despite the devastating nature of outbreaks, always resulting in high mortality and morbidity, a paucity of information exists on the reservoirs of the causative agent, $V$. cholerae, and factors maintaining its persistence. This has complicated disease prevention, resulting in frequent outbreaks of cholera. We investigated water sources in New Bell for contamination with V. cholerae $\mathrm{O} 1$ with pathogenic potential, to highlight their role in disease transmission. Antibiotic susceptibility pattern of isolates and the environmental factors maintaining its persistence were investigated.

Method: Water samples from various sources (taps, dug wells, streams) were analyzed for contamination with $V$. cholerae $\mathrm{O} 1$ using standard methods. Antibiotic susceptibility was determined by disc diffusion method. Pathogenic potential of isolates was determined by analyzing for genes for cholera toxin (ctx), toxin co-regulated pilus (tcpA), and zonula occludens toxin (zot) by PCR. Physico-chemical characteristics of water ( $\mathrm{pH}$, temperature and salinity) were investigated using standard methods. The Spearman's Rank correlation was used to analyze the relationship between physico-chemical factors and the occurrence of $V$. cholerae $O 1$. Differences were considered significant at $\mathrm{P} \leq 0.05$.

Results: Twenty-five $V$. cholerae $\mathrm{O} 1$ strains were isolated from stream and well samples in both dry and rainy seasons. Twenty-three (92\%) isolates were multidrug resistant. All isolates had genes for at least one virulence factor. Cholera toxin gene was detected in 7 isolates. Of the 15 isolates positive for tcpA gene, two had Classical type tcpA while 13 had tсpA El Tor. All tcpA Classical positive isolates were positive for $c t x$ gene. Isolates were grouped into nine genotypes based on the genes analyzed. $\mathrm{pH}$ and salinity significantly correlated with isolation of $\mathrm{V}$. cholerae $\mathrm{O} 1$.
\end{abstract}

Conclusion: Multidrug resistant Vibrio cholerae $\mathrm{O} 1$ with pathogenic potential is present in some wells and streams in study area. pH and salinity are among the factors maintaining the persistence of the organism. Findings indicate an urgent need for potable water supply in study area and in addition, regular disinfection of water from contaminated sources to prevent outbreak of cholera.

Keywords: Vibrio cholerae O1, Cholera, Virulence genes, Antibiotic susceptibility, Multidrug resistance, Environmental factors, Cameroon

\footnotetext{
* Correspondence: jakoachere@yahoo.com

'Department of Microbiology and Parasitology, Faculty of Science, University of Buea, Buea, Cameroon

${ }^{2}$ Laboratory for Emerging Infectious Diseases, Faculty of Science, University of Buea, Buea, Cameroon
} 


\section{Background}

Toxigenic Vibrio cholerae $\mathrm{O} 1$ and $\mathrm{O} 139$ are the causative agents of cholera, an epidemic and life threatening diarrheal disease, which has been a public health concern in most developing countries. Cholera is associated with poor socio-economic conditions, rudimentary sanitary systems and public hygiene, and inadequate supply of potable water. In crowded urban slum and rural areas, epidemics are characterized by high morbidity and mortality. Although $V$. cholerae is a human pathogen, it is autochthonous to the aquatic environment where it persists in the absence of a human host [1] and exists as either a freeliving bacterium or in association with zooplankton. Irrespective of their toxin-producing ability, $V$. cholerae $\mathrm{O} 1$ rarely occurs in natural aquatic environments. Toxigenic strains are rarely isolated from surface water during interepidemic periods. Transmission usually results from drinking contaminated water [2] or eating inadequately cooked foods that have been washed or prepared with contaminated water [3].

The pathogenicity of $V$. cholerae $\mathrm{O} 1$ rests on its ability to express virulence factors like a potent enterotoxin, cholera toxin (CT), and the colonization factor (TCP). These major virulence factors are present in clusters within 2 regions in the $V$. cholerae chromosome: the CTX genetic element which has been reported to comprise the genome of a filamentous phage (CTXФ) [4]; the Vibrio cholerae pathogenicity Island (VPI) that encodes a toxin coregulated pilus (TCP), a type IV pilus that functions in colonization and acts as a receptor for СТХФ. Since СТХФ is a transferrable phage and encodes the cholera toxin [5], acquisition and expression of CT should precede infection by CТХФ. It is generally believed that environmental strains do not produce the cholera toxin gene as such lack the potential to produce epidemic cholera. Other factors associated with enteropathogenicity include hemolysin $(h l y A)$, heat stable enterotoxin (stn/sto), hemagglutinins, neuraminidase, outer membrane protein, shiga-like toxin (stx), a ToxR regulatory protein and the zonula occludens toxin (zot) [6,7]. Genes that code for cholera toxin (ctx) and toxin co-regulated pilus (tcp) are presumed to be exclusively associated with the toxigenic $V$. cholerae strains and are acquired by the bacterium from the aquatic environment [8]. Thus, the aquatic environment may play an important role in the ecology, transmission, and epidemiology of $V$. cholerae. Detection of $V$. cholerae in water is therefore important for disease prevention and control.

Cholera could result in high fatality rates if disease is not properly managed. Although rehydration plays a pivotal role in reducing mortality, antibiotics have been used to reduce the shedding of the organism (thereby reducing spread of the disease), treating severe illness (by reducing volume of diarrhea), and also to reduce duration of disease and hospitalisation. However, the extensive use of antibiotics in therapy and prophylaxis has resulted in the emergence of drug resistant strains in cholera endemic regions $[9,10]$ limiting their use in empiric treatment. This necessitates surveillance of antibiotic susceptibility pattern of the organism not only from clinical isolates but also from environmental isolates in endemic regions as the environment could serve as a reservoir for resistant strains.

In cholera endemic regions, several studies have reported a seasonal pattern of occurrence of $V$. cholerae and cholera [11-13]. This seasonal fluctuation has been attributed to changing environmental factors. Temperature, $\mathrm{pH}$, salinity and nutrient concentration are among the environmental factors shown by field studies to influence the occurrence of the organism [14]. Since the epidemiology of cholera is closely linked to the ecology of $V$. cholerae in the environment, an understanding of the environmental factors that support its persistence and multiplication is crucial for public health protection.

Between 2000 and 2005, Cameroon recorded the highest mean case-fatality rate (10.2\%) of cholera in Africa [15] with most outbreaks occurring in Douala, Cameroon's biggest port city and economic capital. Outbreaks have usually started in the densely populated slums with inadequate sanitation facilities, potable water supply and poor hygiene practices. Despite the regular occurrence of the disease (an indication of persistent presence of $V$. cholerae in the environment), the emergence of drug resistant strains of $V$. cholerae in Douala $[9,16]$ and devastative nature of outbreaks, there still exists a scarcity of data on the reservoirs of the organisms and environmental factors maintaining its persistence in Douala. Inadequate information has complicated disease prediction, prevention and control and has contributed to frequent outbreaks of cholera in Douala.

$V$. cholerae has been reported to contain a distinct class of integrons which permit it to acquire open reading frames and convert them to new functional genes. This implies that not only non-toxigenic strains can acquire virulence genes from the environment but acquisition of antibiotic resistance genes is also possible [17]. Given that the massive use of antibiotics in prophylaxis during previous cholera outbreaks in Douala resulted in the selection of multidrug resistant strains of $V$. cholerae $[9,16]$ current data on antibiotic susceptibility pattern of isolates will update knowledge on appropriate antibiotics for use in empiric treatment in case of an outbreak.

Among the slum areas of Douala, New Bell has been severely affected by cholera epidemics. Outbreaks of the disease have often started from New Bell and this locality has always recorded the highest number of cases and deaths. This study was carried out to isolate and determine the antibiotic susceptibility pattern of $V$. cholerae O1 with pathogenic potential from water sources in 
New Bell and evaluate the physico-chemical factors that maintain its persistence. Findings of this study will not only provoke policies that will drive Cameroon towards the achievement of the Millennium Development Goals target for drinking water but will be of great value in the prevention and control of cholera in study area.

\section{Methods}

Study site

This study was carried out in New Bell (Figure 1), a densely populated neighbourhood in the city of Douala. Douala, is located along the coastal plain of Cameroon and has an equatorial climate with two seasons; the dry season which begins in November and ends in April with January and February as the hottest months [18], the rainy season begins from May to October, August and September having the highest rainfall. However, there is occasional rainfall during the dry season. The New Bell district is one of the areas that have been severely affected by cholera outbreaks. During the 2010-2011 epidemic, the highest number of cases and deaths in the Littoral region were from this locality [19]. Potable water scarcity is an acute problem in New Bell. Since the water table is high, inhabitants rely on shallow wells for water used for drinking and other purposes. Streams in New Bell are used for bathing, washing, recreation and irrigation.

\section{Study design}

Samples were collected from streams, shallow-wells and taps (communal and private standpipes) in New Bell during the dry and rainy seasons and analyzed for $V$. cholerae O1. The public health significance of isolates was determined by analyzing their antibiotic susceptibility pattern and also testing for the presence of genes for virulence factors cholera toxin $(c t x)$, toxin co-regulated pilus $(t c p A)$ and zonular occludens toxin $(z o t)$. The relationship between some environmental factors (temperature, $\mathrm{pH}$ and salinity) and the occurrence of Vibrio cholerae $\mathrm{O} 1$ was studied.

\section{Sample collection}

From March 2010 to January 2011, 300 water samples were aseptically collected from randomly selected streams and house hold sources including shallow wells and taps in New Bell (Figure 1) into sterile glass bottles $(500 \mathrm{~mL})$. A total of 8 streams, 74 wells, and 19 taps were sampled. To collect well or stream sample, a sterile wedge was tied to the sample container and immersed into water until container was full. Stream samples were collected at a depth of about $30 \mathrm{~cm}$ and $2-3 \mathrm{~m}$ away from the bank. Prior to collection of tap water samples, the tap opening was cleaned with $70 \%$ alcohol, and water allowed to flow for 3 minutes to flush out any contaminants. Samples were transported at $4^{\circ} \mathrm{C}$ from site to the laboratory.

\section{Isolation and characterization of $V$. cholerae}

The method described by Islam et al. [20] was employed with slight modification. Ten millilitres $(10 \mathrm{~mL})$ of sample enriched in $5 \mathrm{~mL}$ of triple strength alkaline peptone water (Liofilchem s.r.i. Bacteriology Products, Italy), pH 8.4 overnight at $37^{\circ} \mathrm{C}$. A loop full of enrichment culture was picked just beneath the surface of broth and streaked onto thiosulfate citrate bile salt sucrose (TCBS) agar (Liofilchem s.r.I. Bacteriology Products, Italy) plates and incubated at $37^{\circ} \mathrm{C}$ for 18-24 hours. Presumptive colonies (yellow, measuring 2-4 mm) were sub cultured on brain heart infusion agar to obtain pure cultures. Gram negative, curved and motile rods that were catalase positive, oxidase positive and fermented glucose (but not lactose or sucrose) without gas production or blackening of Kliger Iron Agar medium (Laboratorios Conda, S.A, Spain) were subjected to further biochemical characterization using the API 20E kit (BioMerieux SA, France). Biochemically confirmed Vibrio cholerae were serotyped by slide agglutination as described by $\mathrm{CDC}$ [21] using $V$. cholerae $\mathrm{O} 1$ polyvalent antiserum (Remel Europe Ltd, UK). Isolates that did not show agglutination with polyvalent O1 antiserum were tested with O139 antiserum (Remel Europe Ltd, UK).

\section{Antimicrobial susceptibility testing (AST)}

Susceptibility of isolates to antimicrobial agents was assessed by the disc diffusion (Kirby-Bauer) technique as described by the National Committee for Clinical Laboratory Standards (presently called the Clinical and Laboratory Standards Institute) [22]. A small inoculum of each bacterial isolate was emulsified in $3 \mathrm{~mL}$ of sterile normal saline in Bijou bottles and the density was compared with a barium chloride standard ( 0.5 Mcfarland). A sterile cotton wool was dipped into the standardized suspension of bacterial culture and used to evenly inoculate Mueller-Hinton plates (Biotec, England), and the plates were allowed to dry. Antibiotic discs (Oxoid, Basingstoke, England) with the following drug concentrations: tetracycline $(30 \mu \mathrm{g})$, doxycycline $(30 \mu \mathrm{g})$, amoxicillin $(30 \mu \mathrm{g})$, ampicllin $(30 \mu \mathrm{g})$, trimethroprim-sulfamethoxazole (cotrimoxazole) $(25 \mu \mathrm{g})$, ciprofloxacin $(5 \mu \mathrm{g})$, chloramphenicol $(30 \mu \mathrm{g})$ were placed on the plates. Discs were placed at least $15 \mathrm{~mm}$ apart and from the edge of the plates to prevent the overlapping of zones of inhibition. Plates were incubated at $37^{\circ} \mathrm{C}$ for 24 hours, and the diameters of zones of inhibition were compared with the recorded diameters of the control organism E. coli ATCC 25922 to determine susceptibility or resistance.

\section{Detection of genes for virulence factors (ctxA, tcpA, zot) in $\mathrm{V}$. cholerae 01 isolates}

Isolates were examined for the presence of genes for cholera toxin (ctxA), toxin-coregulated pilus (tcpA) and zonular occludens toxin (zot) by PCR assay. Genes for 


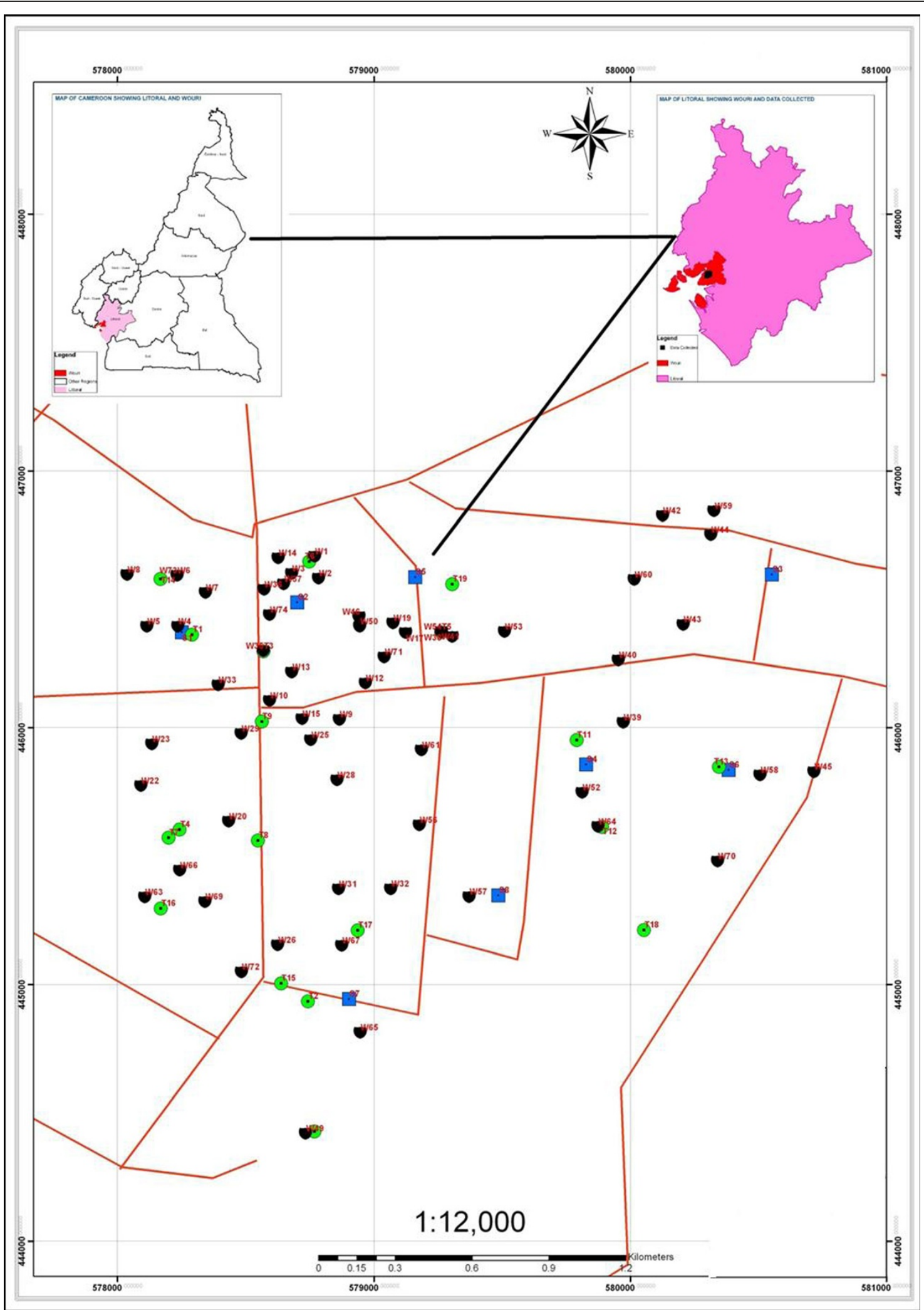

Figure 1 Map of New Bell showing sampling stations. "Green circle symbol" Stream samples, "black semi-circle"Tap samples, "blue square symbol" Well samples, "red lines" Roads. 
the Classical tcpA $\left(t c p A_{C L}\right)$ and $t c p \mathrm{~A}$ El Tor $\left(t c p A_{E T}\right)$ were investigated. DNA isolation from bacterial cell cultures was done using the Qiagen DNeasy kit for Blood and Tissue isolation (Qiagen, Hilden, Germany), following the manufacturer's instructions. Sequences of primers used were as follows: ctx A F: 5'-CTCAGACG GGATTTGTTAGGCACG-3', R:5' -TCTATCTCTGTA GCCCCTATTACG-3' which gave a product size of 302p [23]; tcpA El Tor F: 5'-GAAGAAGTTTGTA AAAGAAGAACAC-3', R: 5'-GAAAGGACCTTCTT TCACGTTG-3' with a product size of 472 bp [23] and tcpA Classical F:5' - CACGATAAGAAAACCGGTCC AAGAG-3', R:5' -ACCAAATGCAACGCCGAATGGAGC3 ', with product size of 618 bp [23]. For zot gene, primer sequences as described by Rivera et al. [24] were as follows: F: 5'-TCGCTTAACGATGGCGCGTTTT-3', R: 5'-AACCCCGTTTCACTTCTACCCA-3' and gave a product with size of $947 \mathrm{bp}$. Oligonucleotide primers were synthesized by Inqaba Biotechnical Industries (Pty) Ltd., South Africa.

Amplification was carried out in $25 \mu \mathrm{L}$ volumes by adding $12.5 \mu \mathrm{L}$ of PCR master mix (Top Taq ${ }^{\mathrm{mi}}$ Master Mix, Qiagen), $0.5 \mu \mathrm{L}$ of each primer, $6.5 \mu \mathrm{L}$ of sterile PCR water and $5 \mu \mathrm{L}$ of bacterial DNA. Two negative controls with PCR water were included in each PCR run. The following amplification conditions described by Islam et al. [23] were used for $c t x \mathrm{~A}, t c p \mathrm{~A}_{\mathrm{ET}}$ and tcp $\mathrm{A}_{\mathrm{CL}}$ genes: an initial denaturation at $94^{\circ} \mathrm{C}$ for 5 minutes, followed by a middle step of 40 cycles for 1 minute each at $94^{\circ} \mathrm{C}$ (denaturation), $56^{\circ} \mathrm{C}$ (annealing of primer) and $72^{\circ} \mathrm{C}$ (DNA polymerase- mediated extension) and a final extension step at $72^{\circ} \mathrm{C}$ for 10 minutes. For zot gene, PCR amplification conditions described by Rivera et al. [24] were used and included an initial denaturation at $94^{\circ} \mathrm{C}$ for 2 minutes, denaturation at $94^{\circ} \mathrm{C}$ for 1 minute, annealing at $60^{\circ} \mathrm{C}$ for 1 minute, an extension step at $72^{\circ} \mathrm{C}$ for 1 minute at the end of 30 cycles and a final extension step at $72^{\circ} \mathrm{C}$ for 10 minutes. PCR was carried out using an automated thermal cycler $\left(\right.$ Bio $\left.\mathrm{Rad}^{\mathrm{m}}\right)$.

Amplification of DNA was analysed electrophoretically in 1.5\% agarose gel for the $c t x A$ and $t c p A$ genes and $1.0 \%$ agarose for zot gene. A 1-kb molecular size marker (New England Biolabs Inc., USA) was used for separation of the amplicons. Gels were stained with the amplified DNA and visualized with a UV transilluminator and photographed using a Gel Documentation-XR reader (BIORAD, Hercules, CA).

\section{Determination of environmental parameters}

Water temperature, $\mathrm{pH}$ and salinity were measured on site immediately after sample collection. Temperature was measured using a thermometer (Chemistry Thermometer, No 3200). $\mathrm{pH}$ was measured using a $\mathrm{pH}$ meter (HANNA Instrument HI 9811, UK). Values for salinity were obtained by measuring conductivity of water samples $(\mu \mathrm{S} / \mathrm{cm})$ using a conductivity meter (HANNA Instrument HI 9811, UK). Conductivity values were then converted to salinity (ppt).

\section{Data analyses}

Statistical Package for Social Science (SPSS) (version 16.0) was used to analyze data. The Chi Square $\left(x^{2}\right)$ test was employed to examine differences in the prevalence of $V$. cholerae $\mathrm{O} 1$ as well as its distribution in water sources. The Spearman's Rank correlation was used to analyze the correlation between physico-chemical parameters and the occurrence of $V$. cholerae $\mathrm{O}$. Wilcoxon Signed Rank ( $Z$ ) test was used to analyze the differences observed in physico-chemical measurements between the dry and the rainy seasons. Differences were considered significant at $\mathrm{P} \leq 0.05$.

\section{Results}

Occurrence of $V$. cholerae 01 in samples

Of the 68 isolates confirmed to be $V$. cholerae, 25 (36.8\%) belonged to serogroup O1 (Table 1). These were isolated from 4 of 8 streams and 14 of 50 contaminated wells (Additional file 1). Among the streams and wells, the highest recovery rate of the organism was in S2, and W25 and W68 where 5, 3, and 2 isolates respectively were obtained. Of the 25 Vibrio cholerae $\mathrm{O} 1$ isolates obtained throughout the period of study, three were detected from March to April 2010 (Additional file 2) before the start of an epidemic in May 2010. Vibrio cholerae $\mathrm{O} 1$ was detected in all the months of our sampling period. Vibrio cholerae O139 was not isolated. We observed co-existence of $V$. cholerae $\mathrm{O} 1$ and non-O1 in all 4 contaminated streams (S1, S2, S4, and S8) and two wells: W33 and W56 (Additional file 1).

\section{Seasonal distribution of $V$. cholerae 01 in various water sources}

A higher frequency of isolation of $V$. cholerae $\mathrm{O} 1$ was recorded in the rainy season $(19 / 49,38.8 \%)$ than in the dry season $(6 / 19,31.6 \%)$. In both seasons the highest rate of isolation was from streams (Table 2). Serogroup O1 was not detected in Tap water samples. There was

Table 1 Prevalence of $V$. cholerae 01 in water samples

\begin{tabular}{llll}
\hline Water source & $\begin{array}{l}\text { Number } \\
\text { of samples } \\
\text { analyzed }\end{array}$ & $\begin{array}{l}\text { Number positive } \\
\text { for } \boldsymbol{V} \text {. cholerae } \\
\text { (\% Positive) }\end{array}$ & $\begin{array}{l}\text { Number } \\
\text { positive for 01 } \\
\text { serogroup (\%) }\end{array}$ \\
\hline Stream $(\mathrm{N}=8)$ & 23 & $17(73.9)$ & $8(47.1)$ \\
Tap $(\mathrm{N}=19)$ & 26 & $1(3.8)$ & $0(0)$ \\
Well $(\mathrm{N}=74)$ & 251 & $50(19.9)$ & $17(34.0)$ \\
Total & $\mathbf{3 0 0}$ & $\mathbf{6 8 ( 2 2 . 7 )}$ & $\mathbf{2 5 ( 3 6 . 8 )}$ \\
\hline
\end{tabular}

$\left(X^{2}=13.578, d f=2, P=0.001\right)$. 
Table 2 Seasonal distribution of $\mathbf{V}$. cholerae 01 in various water sources

\begin{tabular}{lllll}
\hline Season & $\begin{array}{l}\text { Water } \\
\text { sources }\end{array}$ & $\begin{array}{l}\text { No. of samples } \\
\text { analyzed }\end{array}$ & $\begin{array}{l}\text { Number of } \\
\text { isolates (\%) }\end{array}$ & $\begin{array}{l}\text { Serogroup } \\
\text { O1 (\%) }\end{array}$ \\
\hline Dry & Stream & 8 & $6(31.6)$ & $3(50)$ \\
& Tap & 17 & $0(0.0)$ & $0(0.0)$ \\
& Well & 95 & $13(68.4)$ & $3(23.1)$ \\
& Total & $\mathbf{1 2 0}$ & $\mathbf{1 9 ( 1 0 0 . 0 )}$ & $\mathbf{6 ( 3 1 . 6 )}$ \\
Rainy & Stream & 15 & $11(22.5)$ & $5(45.5)$ \\
& Tap & 9 & $1(2.0)$ & $0(0.0)$ \\
& Well & 156 & $37(75.5)$ & $14(37.8)$ \\
& Total & $\mathbf{1 8 0}$ & $\mathbf{4 9 ( 1 0 0 )}$ & $\mathbf{1 9 ( 3 8 . 8 )}$ \\
\hline
\end{tabular}

no significant difference in the isolation of the organism with respect to season $\left(X^{2}=.305, \mathrm{df}=2, \mathrm{P}=0.581\right)$.

\section{Antibiotic sensitivity of $V$. cholerae 01}

All isolates (100\%) were susceptible to ciprofloxacin. Other potent drugs were chloramphenicol (80\%) and doxycycline $(88 \%)$ (Additional file 3 ). $\beta$-lactam antibiotics [ampicillin (8.0\%) and amoxicillin (12.0\%)], tetracycline (32\%) and co-trimoxazole (36\%) had the low susceptibilities. Twenty-three (92\%) isolates were multidrug resistant (resistant to two or more antibiotics). The two isolates that did not show multidrug resistance were obtained from W12 and W68. Nine multidrug resistance patterns were detected (Table 3). Pattern SXT ${ }^{\mathrm{R}} / \mathrm{AML}^{\mathrm{R}} / \mathrm{AMP}^{\mathrm{R}} / \mathrm{TE}^{\mathrm{R}}$ (39.1\%) was the most frequently encountered followed by $\mathrm{AML}^{\mathrm{R}} / \mathrm{AMP}^{\mathrm{R}} / \mathrm{TE}^{\mathrm{R}}$ (17.4\%) and $\mathrm{SXT}^{\mathrm{R}} / \mathrm{AML}^{\mathrm{R}} / \mathrm{AMP}^{\mathrm{R}} / \mathrm{C}^{\mathrm{R}} /$ $\mathrm{TE}^{\mathrm{R}}(13 \%)$.

Amplification of $c t x A, \operatorname{tcpA}$, and zot genes in isolates All 25 isolates were positive for at least one virulence gene (Table 4). Subunit A of the cholera toxin $(\operatorname{ctx} \mathrm{A})$

Table 3 Resistance patterns of $V$. cholerae 01 isolates

\begin{tabular}{|c|c|c|c|}
\hline $\begin{array}{l}\text { Resistance } \\
\text { code }\end{array}$ & Resistance profile & $\begin{array}{l}\text { Number } \\
\text { exhibiting } \\
\text { resistance } \\
\text { profile (\%) }\end{array}$ & Source of isolate \\
\hline R1 & $\mathrm{AML}^{\mathrm{R}} / \mathrm{AMP}^{\mathrm{R}}$ & $1(4.3)$ & S2 \\
\hline R2 & $A M L^{R} / A M P^{R} / C^{R} / T E^{R}$ & $1(4.3)$ & S2 \\
\hline R3 & $\mathrm{AML}^{\mathrm{R}} / \mathrm{AMP}^{\mathrm{R}} / \mathrm{TE} \mathrm{E}^{\mathrm{R}}$ & $4(17.4)$ & S1, W25, W33, W35 \\
\hline R4 & DXT $/ A M L^{R} / A M P^{R}$ & $1(4.3)$ & W68 \\
\hline R5 & $S X T^{R} / A_{M M L} / A M P^{R}$ & $2(8.7)$ & W41, W56 \\
\hline R6 & $S X T^{R} / A_{M L} L^{R} / A_{M P} P^{R} / C^{R}$ & $1(4.3)$ & S2 \\
\hline R7 & $S X T^{R} / A^{\prime} L^{R} / A M P^{R} / C^{R} / E^{R}$ & $3(13.0)$ & S8, W25, W49 \\
\hline R8 & $S X T^{R} / A M L^{R} / A M P^{R} / T E^{R}$ & $9(39.1)$ & $\begin{array}{l}\text { S2*, S4, W4, W53, W60 } \\
\text { W25, W70, W73 }\end{array}$ \\
\hline R9 & $S X T^{R} / A M P^{R}$ & $1(4.3)$ & W16 \\
\hline
\end{tabular}

"Two isolates from S2 exhibited resistance pattern R8. Tetracycline (TE), Chloramphenicol (C), Ampicillin (AMP), Amoxicillin (AML), Cotrimoxazole (SXT), Doxycycline (DXT).
Table 4 Virulence genes in Vibrio cholerae 01 isolated from wells and streams

\begin{tabular}{|c|c|c|c|c|c|c|}
\hline$S / N$ & $c t x A$ & tcpA-El Tor & tcpA-classical & Zot & Source & Season \\
\hline 1 & + & - & - & + & S2 & $\mathrm{D}$ \\
\hline 2 & - & + & ND & - & W33 & $\mathrm{R}$ \\
\hline 3 & - & - & - & + & W73 & $\mathrm{R}$ \\
\hline 4 & - & - & - & + & W35 & $\mathrm{R}$ \\
\hline 5 & - & + & ND & - & W49 & $\mathrm{R}$ \\
\hline 6 & - & + & ND & - & S2 & $\mathrm{R}$ \\
\hline 7 & - & - & - & + & W4 & $\mathrm{R}$ \\
\hline 8 & + & - & + & - & W68 & $\mathrm{R}$ \\
\hline 9 & - & + & ND & + & S2 & $\mathrm{R}$ \\
\hline 10 & - & + & ND & - & W25 & $\mathrm{R}$ \\
\hline 11 & - & - & - & + & W12 & $\mathrm{R}$ \\
\hline 12 & - & - & - & + & W68 & $\mathrm{R}$ \\
\hline 13 & + & + & ND & - & W56 & $\mathrm{R}$ \\
\hline 14 & + & - & - & + & S2 & $\mathrm{R}$ \\
\hline 15 & - & + & ND & - & W60 & $\mathrm{R}$ \\
\hline 16 & - & + & ND & + & S1 & $\mathrm{R}$ \\
\hline 17 & - & - & - & + & W25 & $\mathrm{R}$ \\
\hline 18 & - & + & ND & - & S4 & $\mathrm{R}$ \\
\hline 19 & - & - & - & + & W41 & $\mathrm{R}$ \\
\hline 20 & + & + & ND & + & S2 & $\mathrm{R}$ \\
\hline 21 & - & + & ND & + & W70 & $D$ \\
\hline 22 & + & - & + & + & S8 & $D$ \\
\hline 23 & - & + & ND & - & W53 & $D$ \\
\hline 24 & + & - & - & - & W25 & $D$ \\
\hline 25 & - & + & ND & + & W16 & D \\
\hline
\end{tabular}

ND Not Determined, +: positive, -: negative, $D$ dry season, $R$ rainy season.

gene was amplified in 7 (28\%) isolates. Amplification of the $472 \mathrm{bp} t c p A_{\mathrm{ET}}$ gene occurred in 13 isolates. The gene for $t c p A_{C L}$ was detected in 2 isolates. These 2 isolates were positive for cholera toxin gene with one of them, in addition, being positive for the zot gene. zot gene was amplified in 15 (60\%) isolates (Table 4). Two isolates were positive for all three virulence genes investigated. These organisms were isolated from streams S2 (during the rainy season) and S8 (isolated in the dry season) with the S8 isolate having tcpA of the Classical type (Table 4).

\section{Genotypes of Vibrio cholerae 01 isolates}

Based on the genes analyzed, 9 genotypes of Vibrio cholerae $\mathrm{O} 1$ were identified. Genotypes $c t x A^{-} t c p A E T^{+} z o t^{-}$ (28\%) and $c t x A^{-} t c p A E T z o t^{+}(28 \%)$ were the most frequently detected (Table 5). More than one genotype was detected among isolates from S2, W25, and W68. One isolate from W25 had $\operatorname{ctx} A$ as the only virulence gene. 
Table 5 Genotypes of Vibrio cholerae 01 isolates

\begin{tabular}{|c|c|c|}
\hline Genotype & Source(s) & No. of isolates (\%) \\
\hline$c t \times A^{+} t c p A_{(E T)}^{-} Z O t^{+}$ & $S 2^{*}, \mathrm{~S} 2$ & $2(8)$ \\
\hline$c t \times A^{+} \operatorname{tcp} A_{(c L)}^{+} z o t^{+}$ & S8 & $1(4)$ \\
\hline$c t \times A^{+} t c p A_{(E T)}^{+} Z^{\prime} t^{+}$ & S2 & $1(4)$ \\
\hline$c t \times A^{+} t c p A_{(E T)}^{+} Z O t^{-}$ & W56 & $1(4)$ \\
\hline$c t \times A^{+} t c p A^{+}(C L) Z O t^{-}$ & W68* & $1(4)$ \\
\hline$c t \times A^{+} \operatorname{tcp} A_{(E T)}^{-} z O t^{-}$ & W25* & $1(4)$ \\
\hline$c t \times A^{-} t c p A_{(E T)}^{+} z O t^{-}$ & $\begin{array}{l}\text { S2, S4, W25, W33, } \\
\text { W49, W53, W60. }\end{array}$ & $7(28)$ \\
\hline $\operatorname{ctXA} A^{-} t c p A_{(E T)}^{+} Z O t^{+}$ & S1, S2, W16, W70. & $4(16)$ \\
\hline$c t \times A^{-} t c p A_{(E T)}^{-} Z O t^{+}$ & $\begin{array}{l}\text { W4, W12, W25, W35, } \\
\text { W41, W68, W73. }\end{array}$ & $7(28)$ \\
\hline
\end{tabular}

* Water sources from which more than one genotype of $V$. cholerae O1was isolated.

\section{Environmental factors}

Stream samples recorded the highest temperature in both rainy $\left(26.9^{\circ} \mathrm{C}-31.0^{\circ} \mathrm{C}\right)$ and dry $\left(28.4^{\circ} \mathrm{C}-32.7^{\circ} \mathrm{C}\right)$ season. Generally, temperature values dropped in all samples during the rainy season (Additional file 4). There were no significant differences $(P>0.05)$ in the stream $(Z=-1.389)$ and in tap water temperatures $(Z=-1.781)$ between the rainy and dry season. However, there was a significant difference observed in well water temperatures between the two seasons $(Z=-3.301$, $\mathrm{P}=0.001)$. There was no correlation between temperature and occurrence of $V$. cholerae $\mathrm{O} 1$ in the various water sources in the dry season (Spearman's rho $=-0.069, \mathrm{P}=0.454$ ) and the rainy season (Spearman's rho $=-0.019, \mathrm{P}=0.804)$.

$\mathrm{pH}$ values of samples ranged from slightly acidic to alkaline. The lowest (5.7) and the highest $\mathrm{pH}$ readings (11.3) were recorded in wells in the rainy and dry season respectively (Additional file 4). Although $\mathrm{pH}$ values considerably dropped during the rainy season, the $\mathrm{pH}$ of tap water was fairly constant with no significant difference between the two seasons $(Z=-1.838, P=0.066)$. There were significant differences in the $\mathrm{pH}$ of stream and well water between the rainy and dry season $(Z=-3.748 ; Z=$ -3.531 with $\mathrm{P}<0.05$ for stream and well respectively). There was a significant correlation between $\mathrm{pH}$ and occurrence of $V$. cholerae $\mathrm{O} 1$ in water sources in the dry season (Spearman's rho $=0.227, \mathrm{P}=0.013$ ) and the rainy season (Spearman's rho $=0.380, \mathrm{P}=0.0001$ ).

Values for salinity were generally higher in the rainy season. In the dry season, the highest values were obtained from well samples (1.1 - $5.16 \mathrm{ppt}$ ) (Additional file 4). Highest values in the rainy season were detected in stream samples (1.62 - $11.03 \mathrm{ppt})$. There were significant differences in salinity of samples from all three water sources between the rainy and dry season $(Z=-3.008 ; Z=-3.212$; $\mathrm{Z}=-3.998$ with $\mathrm{P}<0.05$ for stream, tap and well respectively). There was a significant correlation between salinity and isolation of $V$. cholerae $\mathrm{O} 1$ in samples from various sources in the dry season (Spearman's rho $=0.201$, $\mathrm{P}=0.003$ ) and in the rainy season (Spearman's rho = 00.280, $\mathrm{P}=0.0011$ ).

\section{Discussion}

Cholera continues to be a devastating disease of immense public health significance particularly in developing countries. Lack of infrastructure and economic development has made many parts of sub-Saharan Africa vulnerable to cholera, a disease associated with lack of potable water and poor sanitation. Between 2000 and 2005, Cameroon recorded the highest mean casefatality rate (10.2\%) of cholera in Africa [15] with most epidemics occurring in Douala and the northern regions of the country. Since cholera is a treatable disease, casefatality rate reflects access to basic health care. Therefore, cholera prevention and control strategies and data that will strengthen these efforts are of great value to Cameroon's public health.

The prevalence of $V$. cholerae $\mathrm{O} 1$ in samples was low. Of the 68 isolates of $V$. cholerae obtained, only 25 (36.8\%) belonged serogroup O1 (Table 1, Additional file 1). Of these 25 Vibrio cholerae $\mathrm{O} 1$ isolates, three were isolated between March and April before the start of the epidemic in May 2010. The organism was detected during all the months of our study (Additional file 2). Fortythree (43) isolates belonged to the non-O1 serogroup. Previous studies [25] reported a low prevalence of $V$. cholerae $\mathrm{O} 1$ in water in endemic regions. Majority of environmental $V$. cholerae strains have been reported to belong to the non-O1/non-O139 serogroup [14]. Although these non-O1 strains lack epidemic or pandemic potential, some isolates have been reported to possess cholera toxin (ctx) gene and other virulence genes [25] present in $\mathrm{O} 1$ serogroup. Although we did not further investigate the non-O1 isolates for virulence determinants, their presence in our study area should be considered of public health importance and should not be ignored particularly as they have occasionally been isolated from cases of cholera-like diarrhoea [26] and from a variety of extra intestinal infections [27]. In samples where the pathogen was not recovered, it could that either the prevailing environmental conditions in their niche were unfavorable for growth of $V$. cholerae or the source was regularly disinfected (wells and taps). Under unfavorable conditions $V$. cholerae cells have been shown to exist in a viable but non-cultural (VNC) form, [28] which is believed to maintain its persistence in the environment during interepidemic periods. Being that under favourable climatic conditions, VNC $V$. cholerae could revert to a transmissible state, cholera control strategies in endemic areas should be encouraged even when $V$. cholerae is not 
detected in the environment and should include the surveillance for the viable non-culturable state of the organism. The presence of viable but non-culturable cells was not investigated in our study. However, the possibility of the occurrence of the organism in this state in study area has to be considered in future studies, to generate comprehensive data on the occurrence and persistence of $V$. cholerae in study area.

$V$. cholerae $\mathrm{O} 1$ co-existed with non-O1strains in some streams and wells (Additional file 1). Horizontal gene transfer during co-existence of $\mathrm{O} 1$ and non-O1/nonO139 strains [29] has been reported to result in the emergence of novel pathogenic serogroups as well conversion of non-toxigenic strains to toxigenic strains increasing the concentration of toxigenic $V$. cholerae in water and the possibility of an outbreak of cholera.

Vibrio cholerae O139 was not detected during our study. Cholera outbreaks in Africa have been caused by the O1 serogroup. There are no reports of cases due to the O139 infection as this serogroup is confined to Southeast Asia. V. cholerae O1 was isolated only from stream $(47.1 \%, 8 / 17)$ and well $(34.0 \%, 17 / 50)$ samples (Tables 1, 2; Additional file 1) confirming these water sources as reservoirs of the organism in study area. Streams studied are used as dump sites for human and domestic waste. In addition, open drains which carry human wastes empty into these streams. This may explain the high prevalence of the organism in streams. Based on our findings, the use of streams for bathing, recreation and irrigation should be discouraged as this could result in health hazards. The majority of wells were unprotected and due to overcrowding they are located at close proximity to sanitary infrastructures. See page from sanitary facilities through the porous and sandy soil of study area [30] could result in contamination of wells. The only contaminated tap water sample contained Vibrio cholerae non-O1. Municipal water receives adequate treatment before distribution. Contamination could have occurred post treatment through a broken pipe along the distribution network.

Although the rate of isolation of $\mathrm{O} 1$ was slightly higher in the rainy season $(19 / 49,38.8 \%)$ than in the dry season $(6 / 19,31.6)$ (Table 2$)$, the difference was not significant $\left(X^{2}=0.0 .305, P=0.581\right)$. Most parts of study area usually experience floods after heavy rainfall. Flood waters distribute infectious agents from sanitary infrastructures into streams and wells (as majority are poorly constructed) thus contaminating water from these sources. Isolation of the organism in both seasons and in all the months of our study (Table 2, Additional file 2) indicates its presence all year round in study area.

Susceptibility of $V$. cholerae $\mathrm{O} 1$ to antibiotics previously used in prophylaxis and cholera treatment in Douala $[31,32]$ as well as other recommended antibiotics for cholera treatment [33] was analyzed to determine the most appropriate agents for disease management to reduce case fatality rate in the event of an outbreak. Although findings of present study show $100 \%$ susceptibility to ciprofloxacin, there are reports of emergence of ciprofloxacin resistance in other parts of the world [10]. Other drugs with high susceptibility were chloramphenicol (80\%) and doxycycline (88\%) (Additional file 3). Previous studies [32] have also reported high susceptibility of clinical isolates from Douala to these drugs. Our findings thus validate their use in cholera treatment and prophylaxis in Douala. However, to preserve the high potency of ciprofloxacin, doxycycline and chloramphenicol could be used as alternative therapeutic agents.

Resistance to $\beta$-lactams (92\% for ampicillin and $88 \%$ for amoxicillin) as well as tetracycline (68\%) and cotrimoxazole (64\%) was high (Additional file 3). Tatah et al. [34] also reported low susceptibility of $V$. cholerae $\mathrm{O} 1$ and non-O1isolates from another cholera endemic locality in Douala to these drugs. The association between development of resistance and large scale use of these agents for cholera treatment and prophylaxis in Douala is well recognized $[9,16]$. Resistance to these agents has been reported in other developing countries [10]. These antibiotics are also being used extensively or misused for the treatment of other infectious conditions present in study area other than cholera and could have selected for resistant strains in study area. However, strictly prescribed and controlled use of antibiotics for prolonged periods may not affect susceptibility profiles of Vibrio cholerae $[31,35]$. Although drug resistance is not a virulence factor, it may play a role in the selection, persistence and dissemination of pathogenic strains of $V$. cholerae which are difficult to eradicate. Antibiotic resistance has influenced change in policy on cholera treatment in some countries [36] indicating the relevance of knowledge on current susceptibility patterns of pathogens. Our findings highlight the need for constant evaluation of antibiotic susceptibility pattern of $V$. cholerae particularly as it is persistent in New Bell, to understand its epidemiologic features. We tested for antibiotic susceptibility of isolates using the disc diffusion technique. MIC of antibiotics analyzed was not determined. This constitutes a limitation to our study.

The emergence of resistance to various antibiotics among vibrios is a well established phenomenon. Isolates in our study showed a heterogeneous antibiotic resistance pattern with 9 multi-drug resistance (MDR) patterns detected among isolates showing MDR (Table 3). Other studies [37] have reported a lower frequency of multidrug resistant $V$. cholerae than observed in our study. The two isolates (from W12 and W68) not showing multidrug resistance, were resistant to doxycycline but sensitive to chloramphenicol. WHO recommends 
the use of doxycycline or ciprofloxacin as treatment choice for cholera [38]. Ngandjio et al. [9] reported multidrug resistance in all isolates obtained during the 2004-2005 cholera epidemic in Douala. These multidrug resistant strains could have been disseminated into the environment resulting in the high levels reported in our study. Multidrug resistance limits the use of these agents for empiric cholera treatment. Although little is known about the antibiotic susceptibility of epidemic $V$. cholerae strains particularly in African countries, our results indicate that they could pose a public health threat in study area. The high level of multi-drug resistant strains reported in this study and in previous reports from Douala $[9,16]$ indicates the possibility of mobilization of resistance markers among isolates and calls for further studies on plasmid profiles to analyze for the presence of plasmids such as the SXT element, Class 1 integrons [39], transposoons [40] (which have been reported to confer resistance in vibrios) as mechanisms of acquisition of drug resistance genes in our isolates. Since the emergence of such resistance among $V$. cholerae may significantly influence future strategies for cholera control, continuous monitoring of epidemic strains is thus crucial.

Although the majority of environmental $V$. cholerae strains are considered harmless, strains have evolved that cause disease in humans by effectively colonizing the small intestine and releasing potent enterotoxins. To determine the public health significance of isolates, we analyzed for the presence of $c t x \mathrm{~A}$ and $t c p \mathrm{~A}$, which are the major virulence markers of $V$. cholerae; and zot, a supplemental pathogenic factor (Table 4). PCR analysis revealed $28 \%(7 / 25)$ of isolates being toxigenic strains. The rest were negative for $302 \mathrm{bp} c t x$ indicating that these strains do not have the genetic potential to produce cholera toxin. These results are in agreement with the findings of Chakraborty et al. [41] and Alam et al. [13] who reported a low prevalence of toxigenic Vibrio cholerae in environmental samples. This may indicate a better adaptability of non-toxigenic $V$. cholerae over toxigenic strains in water. The El Tor hemolysin has been shown to be the virulence factor responsible for development of diarrhea in non-toxigenic strains [42] making them a public health concern. Cholera toxin production has been detected in CT-positive organisms [43] implying that there is no silent CT gene. Although we did not analyze $c t x$-positive isolates for disease potential, it is important for them to be considered as pathogenic since cholera enterotoxin is a major virulence factor.

Fifteen isolates $(60 \%)$ had genes encoding for the A subunit of toxin co-regulated pilus (TCP) of which 13 had tcpA of the El Tor biotype and 2 positive for $t c p A$ of the Classical biotype. Only four isolates positive for $c t x$ gene were also tcpA positive. Eleven (73.3\%) tcpA positive isolates were negative for the $c t x$ gene. Our finding is contrary to the general notion that most $c t x$ positive strains are also positive for $t c p$. Possession of $t c p A$ therefore suggests that these strains are potentially pathogenic since they have the ability to colonize the human intestine and are susceptible to conversion to toxigenic strains by CTXФ either inside the host intestine or in the aquatic environment. Such $V$. cholerae with latent pathogenic potential have been reported in aquatic environment in other countries $[41,44]$. Two were positive for tcpA Classical gene and the rest two positive for $t c p A_{E T}$. All $t c p A_{C L}$ positive isolates were toxigenic. This is the first report on the presence of the $V$. cholerae with Classical type tcpA in Douala. This finding is of great significance and suggests the possibility of the emergence of strains of the Classical biotype in study area.

Zonular occludens toxin gene was detected in 15 (60\%) isolates indicating a high prevalence of zot in isolates (Table 5). Eleven of these were non-toxigenic. The $z o t$ gene encodes zonular occludens toxin $(z o t)$ described by Fasano et al. [45] as a toxin that increases the permeability of the small intestinal mucosa by affecting the structure of the intercellular tight junctions. Our findings contradict the results of Rivera et al. [24] who reported the absence of $z o t$ in non-toxigenic $V$. cholerae O1. Toxigenic $V$. cholerae have been shown to contain a compound transposoon-like structure, the CTX genetic element which comprises a core region that contains the cholera toxin $\mathrm{A}$ and $\mathrm{B}$ subunits $(\operatorname{ctx} \mathrm{AB})$, zonular occludens toxin $(z o t)$, accessory colonization enterotoxin (ace), an open-reading frame of unknown function (orf $\mathrm{U}$ ) and core-ended pilus (cep) genes. Thus the $z o t$ gene is therefore expected to present in toxigenic $V$. cholerae strains likewise the ctx gene in zot-positive strains. However, Ghosh et al. [46] and Jiang et al. [47] reported the presence of zot gene in non-toxigenic strains, confirming our findings. These findings contradict earlier reports [48] showing that the $z o t$ gene does not occur independently of the $c t x$ genes and as such cannot be used to explain the ability of some $V$. cholerae strains to cause illness in the absence of cholera toxin. Findings of our study indicate the possibility of the СТХФ prophage genome missing or disrupted by mutation, meaning that many CTX $\Phi$ genes among these strains are likely defective, a phenomenon commonly found among all genera of bacteria. However, of the 15 zot-positive isolates, 7 (28\%) contained only zot and 8 isolates carried the $z o t$ and other virulence factors.

Based on the genes investigated, 7 genotypes were observed among $V$. cholerae $\mathrm{O} 1$ isolates with genotypes $c t x \mathrm{~A}^{-} t c p \mathrm{~A}_{\mathrm{ET}}^{+} z o t^{-}(28 \%)$ and $c t x \mathrm{~A}^{-} t c p \mathrm{~A}_{\mathrm{ET}}{ }^{-} z o t^{+}(28 \%)$ predominating. Apart from recording a great diversity of genotypes in study area, we also detected the presence of more than one genotype from same source. Isolates with 
the genotype $c t x^{+} t c p A_{E T}{ }^{-} z o t^{+}$and $c t x^{+} t c p A_{E T}^{-} z o t^{-}$(Table 5) were toxigenic but negative for the $t c p A$. This suggests the presence of a tcp-independent mechanism for infection of these isolates by CTXФ $[49,50]$. These genes studied are located on mobile genetic elements and could be transferred to avirulent strains. However, there was a high prevalence of toxigenic and potentially toxigenic genotypes among isolates.

Sample collection for our study started in March 2010 and by May 2010, an epidemic of cholera was declared in Douala. This may explain the high prevalence of toxigenic $V$. cholerae O1 compared to previous reports [51]. Analysis of DNA fingerprints is necessary to show a link between isolates from present study with those from the 2010-2011 epidemic. Our findings show the necessity for surveillance of $V$. cholerae in aquatic environments in cholera endemic areas of Cameroon to facilitate disease prediction, prevention and control so as to avert the devastating consequences of an epidemic.

The dynamics $V$. cholerae has been shown to be influenced by environmental factors [28,52] through a shift in pathogen or host reservoir species abundance, population dynamics, and community interactions [53]. The influence of environmental factors: temperature, $\mathrm{pH}$ and salinity on occurrence of $V$. cholerae O1was investigated (Additional file 4). Temperature of samples ranged from $22.8^{\circ} \mathrm{C}$ to $31.0^{\circ} \mathrm{C}$ in the rainy season and $26.9^{\circ} \mathrm{C}$ to $33.3^{\circ} \mathrm{C}$ during the dry season. There was no significant difference in stream water temperatures between the rainy and dry season $(Z=-1.389$; with $\mathrm{P}>0.05)$. However, there was a significant variation in temperature of well water samples between the two seasons $(P=0.001)$. There was no correlation between temperature and occurrence of $V$. cholerae $\mathrm{O} 1$ in the various water sources in the dry season (Spearman's rho $=-0.069, \mathrm{P}=0.454$ ) and in the rainy season (Spearman's rho $=-0.019, \mathrm{P}=0.804$ ). Aulet et al. [54] isolated $V$. cholerae in water sources with temperatures ranging from $15^{\circ} \mathrm{C}$ to $26^{\circ} \mathrm{C}$ with optimal isolation at $25^{\circ} \mathrm{C}$. This falls within the temperature range of samples collected during the rainy season in which the recovery rate was higher. Although some studies [55] have reported no correlation in isolation pattern of $V$. cholerae and maximum temperature recorded others $[56,57]$ have reported temperature to correlate with the occurrence of $V$. cholerae, hence an important modulator of environmental concentrations of vibrios. Our study and the report of Dalsgaard et al. [58] showed no correlation between temperature and the isolation of $V$. cholerae. A study with longer duration of sampling in our study area will permit valid conclusions about the influence of temperature on the occurrence of $V$. cholerae.

$\mathrm{pH}$ values ranged from 5.7 to 9.1 in the rainy season and 6.3 to 11.3 in the dry season. There were significant differences in the $\mathrm{pH}$ values of stream and well samples between the rainy and dry season $(Z=-3.748 ; Z=$ -3.531 with $\mathrm{P}<0.05$ for stream and well respectively). There was no significant difference in tap water values between the two seasons $(\mathrm{Z}=-1.838, \mathrm{P}=0.066)$. Optimal $\mathrm{pH}$ for isolation of $V$. cholerae $\mathrm{O} 1$ has been reported to vary between 7.0 and 8.5 and the organism is inactivated at $\mathrm{pH}$ below 4.5 [59]. $\mathrm{pH}$ values reported in this study are similar to the optimal $\mathrm{pH}$ of 8.5 reported by Huq et al. [60] for attachment and multiplication of $V$. cholerae on copepods. There was a significant correlation between $\mathrm{pH}$ and occurrence of $V$. cholerae $\mathrm{O} 1$ in the various water sources in the dry season (Spearman's rho $=0.227, \mathrm{P}=0.013$ ) and the rainy season (Spearman's rho $=0.380, \mathrm{P}=0.0001)$. Our findings contradict the results of Blackwell and Oliver, [57] who reported $\mathrm{pH}$ to have no significant correlation with the isolation of $V$. cholerae in water samples from a major shrimp production area in Thailand.

Salinity ranged between 1.62 and 11.03 ppt in the rainy season and 0.57 and $5.16 \mathrm{ppt}$ in the dry season. There was a significant correlation between salinity and occurrence of $V$. cholerae in the various water sources in the dry season (Spearman's rho $=0.201, \mathrm{P}=0.003$ ) and the rainy season (Spearman's rho $=0.280, \mathrm{P}=0.0011$ ). Salinity has been demonstrated to influence significantly the growth of Vibrio cholerae in cholera endemic areas [14,47]. Salinity values in present study fall within the range for detection of $V$. cholerae (between 2 and 14 ppt, with higher recovery at values below $8 \mathrm{ppt}$ ) reported by Louis et al. [14]. Jiang [47] detected higher concentrations of $V$. cholerae at salinities below 10 ppt but above 0 ppt. Huq et al. [58] reported salinity alone not having an influence on growth of $V$. cholerae at temperatures as low as $10^{\circ} \mathrm{C}$ while at higher temperature the influence of salinity was significant.

\section{Conclusion}

Our results thus demonstrate the presence of diverse genotypes of multidrug resistant toxigenic and potentially toxigenic $V$. cholerae $\mathrm{O} 1$ in New Bell. This study has also demonstrated the presence of toxigenic strains with classical type $t c p A$. Salinity and $\mathrm{pH}$ are some of the factors that could be maintaining its occurrence and persistence of the pathogen in study area. Based on our findings, we recommend the expansion of potable water distribution in New Bell, provision of appropriate sanitary infrastructures, routine well inspection and disinfection as measures for disease prevention in study area.

\section{Additional files}

Additional file 1: Distribution of Vibrio cholerae 01 in various water sources.

Additional file 2: Isolation of $V$. cholerae 01 strains by month. 
Additional file 3: Antibiotic susceptibility of Vibrio cholerae 01 isolates.

Additional file 4: Physico-chemical characteristics of water samples.

\section{Abbreviations}

CDC: Center for disease control and prevention; MINSANTE: Ministere de la sante publique (Ministry of public health).

\section{Competing interests}

The authors declare that they have no competing interests.

\section{Authors' contributions}

JTKA as principal investigator conceived, designed and coordinated the study, interpreted data and initiated the writing of the manuscript. TNM collected samples, isolated and characterized bacteria carried out antimicrobial susceptibility testing and together with HAN carried out molecular studies. All authors read and approved the final manuscript.

\section{Acknowledgements}

This work was carried out in the Laboratory for Emerging Infectious Diseases at the University of Buea and supported by the University of Buea Research Grant No. 2008/A6 awarded to Akoachere J-F TK.

\section{Received: 6 December 2012 Accepted: 31 July 2013}

Published: 7 August 2013

\section{References}

1. Colwell RR: Vibrios in the environment: viable but nonculturable $V$. cholerae. In Vibrio cholerae and Cholera: Molecular to Global Perspectives. Edited by Wachsmuth IK, Blake PA, Olsvik O. Washington DC: ASM Press; 1994:117-133.

2. Ranjbar R, Rahbar M, Naghoni A, Farshad S, Davari A, Shahcheraghi F: A cholera outbreak associated with drinking contaminated well water. Arch Iran Med 2011, 14(5):339-340. 0010.

3. Swaddiwudhipong W, Hannarong S, Peanumlom P, Pittayawonganon C, Sitthi W: Two consecutive outbreaks of food-borne cholera associated with consumption of chicken rice in northwestern Thailand. Southeast Asian J Trop Med Public Health 2012, 43(4):927-932.

4. Waldor MK, Mekalanos JJ: Lysogenic conversion by a filamentous bacteriophage encoding cholera toxin. Science 1996, 272:1910-1914

5. Choi S, Dunams D, Jiang SC: Transfer of cholera toxin genes from 01 to non-01/0139 strains by vibriophages from California coastal waters. J Appl Microbiol 2010, 108(3):1015-1022. doi:10.1111/j.1365-2672.2009.04502.

6. Rivera ING, Chun J, Huq A, Brad Sack R, Colwell RR: Genotypes Associated with Virulence in Environmental Isolates of Vibrio cholerae. Appl Environ Microbiol 2001, 67(6):2421-2429. doi:10.1128/AEM.67.6.2421-2429.2001.

7. Singh DV, Matte MH, Matte GR, Jiang S, Sabeena F, Shukla BN, Sanyal SC, Huq A, Colwell RR: Molecular analysis of Vibrio cholera 01, 0139, non 01, non-0139 strains: clonal relationship between clinical and environmental isolates. App/ Environ Microbiol 2001, 67(2):910-921.

8. Colwell RR: Non-culturable but still viable and potentially pathogenic $V$. cholerae. Zentbl Bakteriol 1993, 279:154-158.

9. Ngandjio A, Tejiokem M, Wouafo M, Ndome I, Yonga M, Guenole A, Lemee L, Quilici M-L, Fonkoua MC: Antimicrobial resistance and molecular characterization of Vibrio cholerae 01 during the 2004 and 2005 outbreak of cholera in Cameroon. Foodborne Pathog Dis 2009, 6(1):49-56.

10. Mandal J, Dinoop KP, Parija SC: Increasing antimicrobial resistance of Vibrio cholerae 01 biotype El Tor strains isolated in a tertiary-care centre in India. J Health Popul Nutr 2012, 30(1):12-16.

11. Mishra A, Taneja N, Sharma M: Environmental and epidemiological surveillance of Vibrio cholerae in a cholera-endemic region in India with freshwater environs. J Appl Micrbiol 2012, 112(1):225-237.

12. Ali $M$, Ryun $D$, Yunus $M$, Emch $M$ : Time series analysis of cholera in Matlab, Bangladesh during 1988-2001. J Health Popul Nutr 2013, 31(1):11-19.

13. Alam M, Sultana M, Nair GB, Sack RB, Sack DA, Siddique AK, Ali A, Huq A, Colwell RR: Toxigenic Vibrio cholerae in the aquatic environment of Mathbaria, Bangladesh. Appl Environ Microb 2006, 72(4):2849-2855.
14. Louis VR, Russek-Cohen E, Choopum M, Rivera ING, Gangle B, Jiang SC, Rubin A, Patz JA, Uhq A, Colwell RR: Predictability of Vibrio cholerae in Chesapeake Bay. Appl Environ Microb 2003, 69:2773-2775.

15. Gaffga NH, Tanxe RV, Mintz ED: Cholera: A New Homeland in Africa? Am J Trop Med Hyg 2007, 77(4):705-713.

16. Garrigue GP, Ndayo M, Sicard JM, Fonkoua MC, Lemao G, Durand JP, Dodin A: Antibiotic resistance of strains of Vibrio cholerae El Tor isolated in Douala (Cameroon). B Soc Pathol Exot 1986, 79(3):305-312

17. Faruque SM, Albert MJ, Mekalanos JJ: Epidemiology, genetics and ecology of toxigenic Vibrio cholerae. Microbiol Mol Biol R 1998, 62(4):1301-1314.

18. Maffany GT: Impact of the geology and seawater intrusion on the groundwater quality in Douala, MSc thesis. Department of Geology and Environmental Science, University Buea; 1999.

19. Ministere de la Sante Publique (MINSANTE): Reunion hebdomadaire sur la surveillance des maladies a potential epidemique et des situations d'urgence au Cameroun. 2011. www.minsante.gov.cm.

20. Islam MS, Hasan MK, Miah MA, Yunus M, Zaman K, Albert MJ: Isolation of Vibrio cholerae 0139 synonym Bengal from the aquatic environment in Bangladesh: implications for disease transmission. Appl Environ Microbiolo 1994, 60(5):1684

21. Cheryl AB, Allen AR, Joy GW: Laboratory Methods for the Diagnosis of Epidemic Dysentery and Cholera. Atlanta Georgia: Center for Disease Control and Prevention; 1999.

22. National Committee for Clinical Laboratory Standards: Performance standard for antimicrobial disc susceptibility tests: approved standards. 6th edition. Wayne, PA: NCCLS document M2-A6; 2003.

23. Islam MS, Jahid MIK, Rahman MM, Rahman MM, Kabir MS, Sack DA, Schoolnick GA: Biofilm acts as microenvironment for plankton-associated Vibrio cholerae in the aquatic environment of Bangladesh. Microbiol Immunol 2007, 51(4):369-379.

24. Rivera ING, Chun J, Huq A, Sack RB, Colwell RR: Genotypes associated with virulence in environmental isolates of Vibrio cholerae. Appl Environ Microb 2001, 67:2421-2429

25. Islam MS, Drasar BS, Sack RB: The aquatic flora and fauna as reservoirs of Vibrio cholerae: a review. J Diarrhoeal Dis Res 1994, 12:87-96.

26. Ramamurthy T, Bag PK, Pal A, Bhattacharya SK, Bhattacharya MK, Shimada T, Takeda T, Karasawa T, Kurazono H: Virulence patterns of Vibrio cholerae non-01 strains isolated from hospitalized patients with acute diarrhea in Calcutta, India. J Med Microbio/ 1993, 39:310-317.

27. Issa H, Shorman M, Bseiso B, Al-Salem AH: A case of 01 Vibrio cholerae bacteremia and primary peritonitis in a patient with liver cirrhosis. Gastro Res 2009, 2(6):358-360.

28. Colwell RR: Global climate and infectious disease: the cholera paradigm. Science 1996, 274:2025-2031.

29. Faruque SM, Sack DA, Sack RB, Colwell RR, Takeda Y, Nair GB: Emergence and evolution of Vibrio cholerae 0139. Proc Natl Acad Sci USA 2003, 100:1304-1309.

30. Guevart E, Noeske J, Essomba JM, Edjenguele M, Bita A, Mouangue A, Manga B: Factors contributing to endemic cholera in Douala, Cameroon. Med Trop 2006, 66(3):283-291.

31. Noeske J, Guévart E, Kuaban C, Solle J, Fonkoua MC, Mouanque A, Fouda $A B$ : Routine use of antimicrobial drugs during the 2004 cholera epidemic in Douala, Cameroon. E Afr Med J 2006, 83(11):596-601.

32. Guévart E, Noeske J, Sollé J, Mouangue A, Bikoti JM: Large-scale selective antibiotic prophylaxis during the 2004 cholera outbreak in Douala (Cameroon). Sante 2007, 17(2):63.

33. Cholera-Vibrio cholerae Infection: Antibiotic Treatment. http://www.cdc/ cholera/treatment/antibiotic-treatment.html.

34. Tatah AJ-FK, Pulcherie KMC, Mande NL, Akum NH: Investigation of water sources as reservoirs of $V$. cholerae in Bepanda, Douala and determination of physic-chemical factors maintaining its endemicity [abstract]. Onderstepoort J Vet Research 2012, 72(2):484.

35. Guévart E, Solle J, Mouangue A, Noeske J, Bita A, Fonkoua MC, Wouafo NWM: of Vibrio cholerae 01: evolution after prolonged curative and preventive use during the 2004 cholera epidemics in Douala (Cameroon). Med Mal Infect 2006, 36(6):329-34.

36. Mwansa JC, Mwaba J, Lukwesa C: Multiply antibiotic-resistant Vibrio cholerae $\mathrm{O} 1$ biotype El Tor strains emerge during cholera outbreaks in Zambia. Epidemiol Infect 2006, 135:847-53.

37. Kumar PA, Patterson J, Karpagam P: Multiple antibiotic resistance profiles of V. cholerae non-01 and non-0139. Jpn J Infect Dis 2009, 62:230-232. 
38. Sack DA, Lyke C, McLaughlin C, Suwanvanichkij V: Antimicrobial resistance of shigellosis, cholera and campylobacteriosis. Geneva: World Health Organization; 2001:8-21.

39. Dalsgaard A, Forslund A, Sandvang D, Arntzen L, Keddy K: Vibrio cholerae 01 outbreak isolates in Mozambique and South Africa in 1998 are multiple-drug resistant; contain the SXT element and the aadA2 gene located on class 1 integrons. J Antimicrob Chemoth 2001, 48(6):827-38.

40. Waldor MK, Tschape H, Mekalanos JJ: A new type of conjugative transposoon encodes resistance to sulfamethoxazole, trimethoprim and streptomycin in Vibrio cholerae 0139. J Bacteriol 1996, 178:4157-4165.

41. Chakraborty S, Mukhopadhyay AK, Bhadra RK, Ghosh AN, Mitra R, Shimada T, Yamasaki S, Faruque SM, Takeda Y, Colwell RR, Nair GB: Virulence genes in environmental strains of Vibrio cholerae. Appl Environ Microb 2000 66:4022-4028

42. Pichel M, Marta R, Chinen I, Martin F, Ibarra C, Binsztein N: Genetic diversity of Vibrio cholerae 01 in Argentina and emergence of a new variant. J Clinl Microbiol 2003, 41(1):124-134.

43. Minami A, Hashimoto S, Abe H, Arita M, Taniguchi T, Honda T, Miwatani T, Nishibuchi M: Cholera enterotoxin production in Vibrio cholerae 01 strains isolated from environment and from humans in Japan. Appl Environ Microb 1991, 57:2152-7.

44. Shinoda S, Iwasaki M, Sonoda T, Furmai Y, Miyake-Nakayama C, Katayama S: Ecological study of $V$. cholerae in aquatic environments, Okayama. Biocontrol Sci 2010, 15(3):117-121.

45. Fasano A, Baudry B, Pumplin DW, Wasserman SS, Tall BD, Ketley JM, Kaper JB: Vibrio cholerae produces a second enterotoxin, which affects intestinal tight junctions. Proc Natl Acad Sci USA 1991, 88:5242-5246.

46. Ghosh C, Nandy RK, Dasgupta SK, Nair GB, Hall RH, Ghose AC: A search for cholera toxin co-regulated pilus (TCP), the regulatory element (ToxR) and other virulence factors in non-01/non-0139 V. cholerae. Microb Pathogenesis 1997, 22:199-415.

47. Jiang SC: Vibrio cholerae in recreational beach waters and tributaries of Southern California. Hydrobiologia 2001, 460:157-164.

48. Johnson JA, Morris JG Jr, Kaper JB: Gene encoding zonula occludens toxin (zot) does not occur independently from cholera toxin genes (ctx) in Vibrio cholerae. J Clin Microbiol 1993, 31(3):732

49. Boyd EF, Waldor MK: Evolutionary and functional analysis of variants of the toxin co-regulated pilus protein TcpA from toxigenic Vibrio cholerae non-01/non-0139 serogroups isolates. Microbiology 2002, 148:1655-66.

50. Faruque SM, Rahman MM, Islaml AKM, Mekalanos JJ: Lysogenic conversion of environmental Vibrio mimicus strains by CTXФ. Infect Immun 1999, 67:5723-5729

51. Wouafo MN, Noeske J, Pouillot R, Ngandjio A, Ejenguele G, Quilici M-L: Environmental determinants associated with V. cholerae in Douala, Cameroon. Rapport Scientifique Final Portant sur le Projet Intitulé; 2007. www.imea.fr/ imea-fichiersjoints/imea-projects-soutenus/0506-Poster.

52. Lipp E, Huq A, Colwell RR: Effects of global climate on infectious disease: the cholera model. Clinical Microbiol Rev 2002, 15:757-770.

53. Koelle K, Pascual M, Yunus MD: Pathogen adaptation to seasonal forcing and climate change. Proc Biol Sci 2005, 272(1566):971-977.

54. Aulet O, Silva C, Fraga SG, Piche M, Cangemi R, Gaudioso C, Porcel N, Jure MA, Cecilia de Castillo M, Binsztein M: Detection of viable and viable nonculturable Vibrio cholerae $\mathrm{O} 1$ through cultures and immunofluorescence in the Tucumán rivers, Argentina. Rev Soc Bras Med Trop 2007, 40(4):385-390.

55. Jesudason MV, Balaji V, Mukundan U, Thomson CJ: Ecological study of Vibrio cholerae. Epidemiol and Infect 2000, 124:201-206.

56. del Refugio M, Castañeda C, Sedas VP, Borunda EO, Reynoso FL: Influence of water temperature and salinity on seasonal occurrences of Vibrio cholerae and enteric bacteria in oyster-producing areas of Veracruz, México. Mar Pollut Bull 2005, 50(12):1641-1648.

57. Blackwell KD, Oliver JD: The ecology of Vibrio vulnificus, V. cholerae and V. parahaemolyticus in Northern Carolina estuaries. J Microbiol 2008 , 46(2):146-53. doi:10.1007/s12275-007-0216-2.

58. Dalsgaard A, Huss HH, H-Kittikun A, Larsen JL: Prevalence of vibrio cholerae and salmonella in a major shrimp production area in Thailand. Int J Food Microbiol 1995, 28(1):101-13.
59. World Health Organisation: Cholera, 2006. Weekly Epidemiological Record 2007, 82(31):273-284.

60. Huq A, West PA, Small EB, Huq MI, Colwell RR: Influence of water temperature, salinity, and $\mathrm{pH}$ on survival and growth of toxigenic Vibrio cholerae serovar $\mathrm{O} 1$ associated with live copepods in laboratory microcosms. Appl Environ Microb 1984, 48(2):420-424.

doi:10.1186/1471-2334-13-366

Cite this article as: Akoachere et al.: Multi-drug resistant toxigenic Vibrio cholerae $\mathrm{O} 1$ is persistent in water sources in New Bell-Douala,

Cameroon. BMC Infectious Diseases 2013 13:366.

\section{Submit your next manuscript to BioMed Central and take full advantage of:}

- Convenient online submission

- Thorough peer review

- No space constraints or color figure charges

- Immediate publication on acceptance

- Inclusion in PubMed, CAS, Scopus and Google Scholar

- Research which is freely available for redistribution

Submit your manuscript at www.biomedcentral.com/submit
C) BioMed Central 